\title{
Effects of melatonin on HIF-1 $\alpha$ and VEGF expression and on the invasive properties of hepatocarcinoma cells
}

\author{
JUCIMARA COLOMBO $^{1}$, JOÃO MARCOS WOLF MACIEL ${ }^{2}$, LÍVIA CARVALHO FERREIRA ${ }^{1,3}$, \\ RENATO FERREIRA DA SILVA ${ }^{4}$ and DEBORA APARECIDA PIRES DE CAMPOS ZUCCARI ${ }^{1,3,5}$ \\ ${ }^{1}$ Laboratory of Molecular Investigation of Cancer (LIMC); ${ }^{2}$ Department of Molecular Biology, \\ Faculdade de Medicina de São José do Rio Preto (FAMERP), São José do Rio Preto, São Paulo, SP 15090-000; \\ ${ }^{3}$ Postgraduate Program in Genetics, Universidade Estadual Paulista "Júlio de Mesquita Filho" - UNESP/IBILCE, \\ São José do Rio Preto, São Paulo, SP 15054-000; Departments of ${ }^{4}$ Surgery and ${ }^{5}$ Molecular Biology, \\ Faculty of Medicine of São José do Rio Preto, São José do Rio Preto, São Paulo, SP 15090-000, Brazil
}

Received March 12, 2015; Accepted April 1, 2016

DOI: $10.3892 / \mathrm{ol} .2016 .4605$

\begin{abstract}
Liver cancer is the sixth most commonly occurring cancer globally, and the main histological type is hepatocellular carcinoma. This type of neoplasia has a poor prognosis due to a high rate of recurrence and intrahepatic metastasis, which are closely are closely associated with the angiogenic process. Vascular endothelial growth factor (VEGF), which is under the control of hypoxia inducible factor- $1 \alpha$ (HIF-1 $\alpha$ ), stimulates the proliferation of endothelial cells and increases cell permeability, promoting the growth, spread and metastasis of tumors. Melatonin, the main hormone secreted by the pineal gland, may have a significant role in tumor suppression and has demonstrated antiangiogenic and antimetastatic effects. The aim of the present study was to analyze the cell viability, migration and invasion, as well as the expression of proangiogenic proteins VEGF and HIF-1 $\alpha$, in HepG2 hepatocarcinoma cells, following treatment with melatonin. Cells were cultured and cell viability was investigated using 3-(4,5-dimethylthiazol-2-yl)-2,5-diphenyltetrazolium bromide (MTT) assay. The expression of proangiogenic proteins VEGF and HIF-1 $\alpha$, under conditions of normoxia and hypoxia, was verified using immunocytochemistry and quantified by densitometry. The analysis of the processes of cell migration and invasion was
\end{abstract}

Correspondence to: Dr Debora Aparecida Pires de Campos Zuccari, Laboratory of Molecular Investigation of Cancer (LIMC), Faculdade de Medicina de São José do Rio Preto (FAMERP), Avenida Brigadeiro Faria Lima, 5416, Vila São Pedro, São José do Rio Preto, Sao Paulo, SP 15090-000, Brazil

E-mail: debora.zuccari@famerp.br

Abbreviations: AU, arbitrary units; FBS, fetal bovine serum; MTT, 3-(4,5-dimethylthiazol-2-yl)-2,5 diphenyltetrazolium bromide; HIF-1 $\alpha$, hypoxia-inducible factor $1 \alpha$; MOD, mean optical density; VEGF, vascular endothelial growth factor

Key words: liver cancer, HepG2, vascular endothelial growth factor, hypoxia-inducible factor $1 \alpha$, invasion assay, melatonin performed in a Boyden chamber. The MTT assay revealed a reduction in cell viability $(\mathrm{P}=0.018)$ following treatment with $1 \mathrm{mM}$ melatonin for $24 \mathrm{~h}$. The expression of proangiogenic proteins VEGF and HIF-1 $\alpha$ was reduced in cells treated with $1 \mathrm{mM}$ melatonin for $24 \mathrm{~h}$ in normoxic $(\mathrm{P}<0.001)$ and hypoxic $(\mathrm{P}<0.001)$ conditions, compared with the control group and with induced hypoxia alone. The rate of cell migration and invasion was additionally reduced in cells treated with $1 \mathrm{mM}$ melatonin for $48 \mathrm{~h}$ when compared with the control group $(\mathrm{P}=0.496)$. The results of the present study suggest that melatonin may have an antiproliferative, antiangiogenic and antimetastatic role in hepatocarcinoma cells and may present a novel therapeutic option for the treatment of liver cancer.

\section{Introduction}

Hepatocellular carcinoma (HCC) is the most commonly observed type of liver cancer, accounting for $80 \%$ of cases (1). Regarding incidence, liver cancer is the sixth most common cancer and the third most common cause of cancer-associated mortality (1). The choices for treatment, particularly for advanced HCC, are limited and the prognosis is poor (2). This is due to the fact that the tumors are typically diagnosed at a late stage (2).

HCC tumors are characterized by neovascularization and a high propensity for venous invasion (3). Increased neovascularization is a major clinicopathological feature of hepatocellular carcinoma, and tumor microvessel density is closely associated with disease progression and patient prognosis (3). Vascular endothelial growth factor (VEGF) is one of the most potent proangiogenic agents, which specifically stimulates the proliferation of endothelial cells and increases cell permeability (4). This factor is involved in angiogenesis in multiple tumor types, promoting growth, spread and tumor metastasis (5). Previous studies have correlated increased VEGF expression with poor prognosis in HCC $(6,7)$.

The expression of VEGF in tumor cells is under the control of hypoxia inducible factor- $1 \alpha$ (HIF-1 $\alpha$ ), a transcription factor that is induced in hypoxic conditions, which consists of two subunits: HIF-1 $\alpha$ and HIF-1 $\beta$ (8). Increased expression of 
HIF-1 $\alpha$ and/or VEGF results in activation of angiogenesis, which is associated with malignant progression and increased invasive and metastatic potential of tumor cells (9-11), representing an adverse prognostic factor in the treatment of cancer $(10,12,13)$.

Tumor recurrence in hepatocarcinoma may occur as metastasis and $>90 \%$ of HCC-associated deaths are the result of secondary local or distant disease (14). Metastasis and invasion are strongly dependent on the ability of tumor cells to migrate (15). In general, the earliest occurrence of metastasis of primary liver cancer is the invasion of the hepatic portal vein, the branches of which then for a tumor thrombus, which facilitates intrahepatic metastatic proliferation (16). Extrahepatic metastatic sites include lung (55\%), lymph nodes (53\%), bone (28\%), adrenal glands (11\%), peritoneum and/or omentum (11\%) and brain (2\%) (17).

As hepatocarcinoma presents a high rate of mortality and morbidity, there is an increasing interest in the identification of novel therapeutic agents which are able to interact with specific molecular markers, primarily associated with angiogenesis and invasion, and leading to inhibition of tumor progression (16).

Melatonin, a hormone naturally produced and secreted in the pineal gland, has been demonstrated to be effective in tumor inhibition in in vitro and in vivo studies $(18,19)$. This hormone exerts oncostatic activity through a variety of mechanisms, including antiproliferative actions, anticancer immunity stimulation, modulation of expression of oncogenes, antiinflammatory, antioxidant, antiangiogenic and antimetastatic effects (20).

In vitro studies have reported that melatonin is able to inhibit the expression of HIF-1 $\alpha$ in prostate cancer cells (21) and glioblastoma (22), as well as VEGF expression in breast (23) and pancreatic cancer cells (5), as well as glioblastoma (22). Carbajo-Pescador et al (24) reported that melatonin exerted antiangiogenic activity in HepG2 cells by interfering with the transcriptional activation of the VEGF gene by HIF- $1 \alpha$ and signal transducer and activator of transcription 3 .

Experimental results have additionally indicated that melatonin may be capable of reducing migration and invasiveness in glioblastoma (22,25), lung (26) and breast cancer cells (27-29). However, much remains to be elucidated regarding the antimetastatic properties of melatonin in HCC cells.

As angiogenesis and metastasis are two fundamental processes in tumor progression and are associated with patient prognosis and survival, the present study aimed to evaluate the expression of the proangiogenic proteins HIF- $1 \alpha$ and VEGF and the invasion ability, a parameter of metastatic potential, in a hepatocarcinoma cell line following treatment with melatonin.

\section{Materials and methods}

Cell culture. In the present study the HepG2 cell line was used, which was kindly provided by Dr Bruno Cogliati from the Department of Pathology, College of Veterinary Medicine, University of São Paulo (São Paulo, Brazil) and were originally purchased from the American Type Culture Collection (Manassas, VA, USA). The HepG2 cell line is derived from the liver tissue of a 15-year-old Caucasian male with differentiated hepatocellular carcinoma.
Cells were maintained at $37^{\circ} \mathrm{C}$ in an atmosphere of $5 \% \mathrm{CO}_{2}$ in Dulbecco's modified Eagle's medium (DMEM; Cultilab Materiais Cultura Células, São Paulo, Brazil), supplemented with 10\% fetal bovine serum (FBS; Cultilab Materiais Cultura Células), $1 \%$ penicillin/streptomycin (Sigma-Aldrich, St. Louis, MO, USA). Cells were passaged every 7 days.

Test of cell viability by 3-(4,5-dimethylthiazol-2-yl)-2,5-diphenyltetrazolium bromide (MTT) assay. The individual wells of a 96-well plate (Sarstedt, Nümbrecht, Germany) were inoculated with $100 \mu$ l DMEM containing $5 \times 10^{4}$ cells. Cells were incubated in DMEM with various concentrations of melatonin (Sigma-Aldrich; 1 and $100 \mathrm{nM}, 10 \mu \mathrm{M}$ and $1 \mathrm{mM}$ ) for $24 \mathrm{~h}$. Melatonin was diluted in $50 \mu \mathrm{l}$ ethanol $(0.05 \%$; Dinâmica, São Paulo, Brazil). In control cells, the equivalent amount of ethanol was added as vehicle. Following $24 \mathrm{~h}$ of treatment with melatonin, the culture medium was discarded and $100 \mu \mathrm{l}$ fresh DMEM was added to each well. Subsequently, $10 \mu \mathrm{l}$ of MTT solution at $12 \mathrm{mM}$ (Thermo Fisher Scientific, Inc., Waltham, MA, USA) was added to each well and the plate was incubated at $37^{\circ} \mathrm{C}$ for an additional $4 \mathrm{~h}$. To solubilize the formazan crystals, the cells were incubated with dimethyl sulfoxide (Sigma-Aldrich).

The plate was incubated at $37^{\circ} \mathrm{C}$ for $10 \mathrm{~min}$ and the samples were homogenized prior to assessment of the absorbance using an ELISA reader (Multiskan ${ }^{\mathrm{TM}}$ FC Microplate Photometer; Thermo Fisher Scientific, Inc.) at a wavelength of $540 \mathrm{~nm}$. DMEM was used as background and its absorbance value was subtracted from that of the samples to avoid interference in the results. Cell viability (\%) was calculated for all groups compared to the control sample. All experiments were performed in triplicate.

Treatment of cells in vitro. Cells were divided into the following groups: Control cells (untreated), hypoxic cells (treated with $100 \mu \mathrm{M} \mathrm{CoCl}_{2}$ ), hypoxic cells treated with $1 \mathrm{mM}$ melatonin and normal cells treated with $1 \mathrm{mM}$ melatonin for $24 \mathrm{~h} \mathrm{(30)}$. These treatment conditions were used for immunocytochemistry assay.

Immunocytochemistry. For immunocytochemistry techniques, $0.5 \times 10^{6}$ cells in culture were transferred to a slide with coupled flask (Thermo Fisher Scientific, Inc.) and incubated at $37^{\circ} \mathrm{C}$ for $24 \mathrm{~h}$. Following this period, the culture medium was removed and the cells were washed with phosphate-buffered saline (PBS). To fix the cells, the flask was incubated with $1 \mathrm{ml}$ of $4 \%$ formaldehyde (Sigma-Aldrich) for $20 \mathrm{~min}$.

Subsequently, the flasks were uncoupled from the slides and incubated with $10 \%$ hydrogen peroxide for $30 \mathrm{~min}$ to block endogenous peroxidase activity. Antigen retrieval was performed in a pressure cooker (ARNO, São Paulo, SP, Brazil) at $95^{\circ} \mathrm{C}$ with citrate buffer ( $\mathrm{pH}$ 6; Dinâmica) for $30 \mathrm{~min}$. Following cooling, the slides were immersed in a solution of bovine serum albumin and incubated for at $4^{\circ} \mathrm{C}$ overnight with primary antibodies for HIF-1 $\alpha$ (mouse monoclonal anti-human; dilution, 1:50, catalog no., sc-53546; Santa Cruz Biotechnology, Inc., Dallas, TX, USA) and VEGF (rabbit polyclonal anti-human; dilution, 1:500, catalog no., sc-152; Santa Cruz Biotechnology, Inc.). Subsequently, the samples were washed with PBS for $15 \mathrm{~min}$ and incubated with the 
Starr Trek Universal HRP Detection System (catalog no., STUHRP700 H, L10; Biocare Medical, Inc., Concord, CA, USA), which consisted of biotinylated secondary antibody (anti-mouse, anti-rabbit and anti-goat immunoglobulins) that was incubated with the samples for $20 \mathrm{~min}$ at room temperature, and streptavidin-peroxidase complex that was incubated at room temperature with the samples for $10 \mathrm{~min}$, followed by washing with PBS for $15 \mathrm{~min}$. Subsequently, diaminobenzidine-tetrahydrochloride-dihydrate (Covance Laboratories, Dedham, MA, USA) was applied as a chromogen for $5 \mathrm{~min}$ at $22^{\circ} \mathrm{C}$. The slides were counterstained with Harris's hematoxylin (CARLO ERBA Reagents, Milan, Italy) for $40 \mathrm{sec}$.

Evaluation of immunocytochemical staining by optical densitometry. Various fields were examined on each slide, particularly areas delimited with brown staining. The slides were photographed, and protein expression was quantified using Image $\mathbf{J}$ software (imagej.nih.gov/ij/) at magnification, x40 on a Nikon Eclipse E200 microscope (Nikon Corp., Tokyo, Japan). For each slide, 3 images were captured (Eurekam; Bel Photonics, Piracicaba, Brazil). A total of 20 regions of interest were randomly selected in each image. The intensity was determined from a total of 60 regions of interest marked on each slide. The values were obtained as arbitrary units (AU), and the mean optical density (MOD) revealed the intensity of staining in specifically immunoreactive areas (31).

Invasion assay. The invasiveness of $\mathrm{HepG} 2$ cells was assessed using Transwell chambers with an $8-\mu \mathrm{m}$ pore size membrane (Corning Inc., Corning, NY, USA). In the upper compartment of the chamber, $\sim 2.5 \times 10^{4}$ cells/insert were added into DMEM without serum, while to the lower compartment $750 \mu \mathrm{l}$ of DMEM (with 5 and 10\% FBS for negative and positive controls, respectively) was added with $1 \mathrm{mM}$ melatonin.

The cells were incubated at $37^{\circ} \mathrm{C}$ in at atmosphere of $5 \%$ $\mathrm{CO}_{2}$ for $48 \mathrm{~h}$. Following incubation, the Transwell membranes were washed and impermeabilized. The invading cells were stained with hematoxylin and the non-migrating cells were removed from the upper surface of the Transwell membrane using a cotton swab. Cell counting was performed under an inverted optic microscope by placing the cell invasion assay insert over a plate containing 50\% glycerol (Sigma-Aldrich).

The invasiveness of HepG2 cells was assessed in 24-well plates with $8-\mu \mathrm{m}$ pore size Matrigel-coated membranes (BD Biosciences, Billerica, MA, USA). Cell invasion (\%) of each group was calculated from the mean values of cells that migrated and invaded the Matrigel membrane in duplicate. The positive control group was assumed to represent $100 \%$. The result was calculated from the difference compared to the positive control group.

Statistical analysis. The results were submitted to analysis of normal distribution using column statistics and the Gaussian distribution test. The means of optical densitometric analysis associated with the expression of VEGF and HIF- $1 \alpha$ proteins were compared in various groups, using analysis of variance, followed by the Bonferroni correction. Differences between the groups in the invasion assay were evaluated by Student's $t$-test.

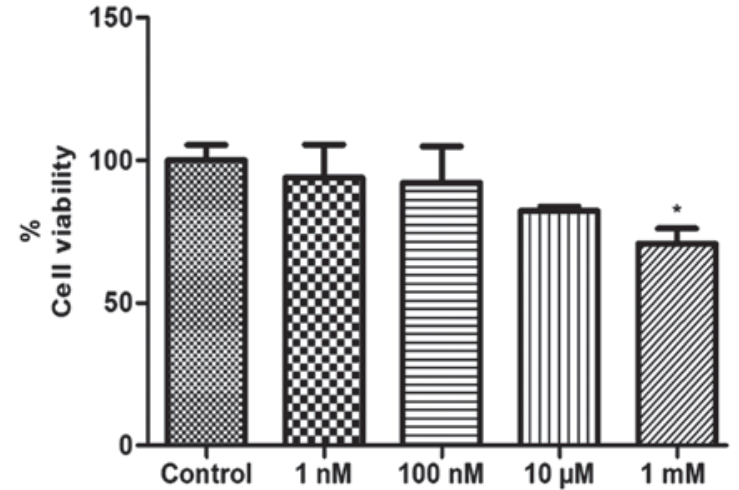

Figure 1. Analysis of cell viability by 3-(4,5-dimethylthiazol-2-yl)-2,5-diphenyltetrazolium bromide assay in liver cancer cells following $24 \mathrm{~h}$ of treatment with melatonin $(1 \mathrm{nM}, 100 \mathrm{nM}, 10 \mu \mathrm{M}$ and $1 \mathrm{mM})$. Data are expressed as a percentage of the control group, and presented as the mean \pm standard deviation. ${ }^{*} \mathrm{P}<0.05$ compared with the control.

All values are expressed as the mean \pm standard deviation. $\mathrm{P}<0.05$ was considered to indicate a statistically significant difference. All analyses were performed using GraphPad Prism 4 software version 5.01 (GraphPad Software, Inc., La Jolla, CA, USA).

\section{Results}

Test of cell viability by MTT assay. The number of viable cells was evaluated by MTT assay following treatment with melatonin ( 1 and $100 \mathrm{nM}, 10 \mu \mathrm{M}$ and $1 \mathrm{mM}$ ) for $24 \mathrm{~h}$. The results demonstrated that treatment with concentrations of $1 \mathrm{nM}, 100 \mathrm{nM}$ and $10 \mu \mathrm{M}$ melatonin did not alter the viability of the HepG2 cells following $24 \mathrm{~h}$ of treatment $(\mathrm{P}=0.6550$; $\mathrm{P}=0.5977$; and $\mathrm{P}=0.0837$, respectively; Fig. 1). Only $1 \mathrm{mM}$ melatonin, the pharmacological concentration, significantly decreased the viability of HepG2 cells relative to the control cells ( $\mathrm{P}=0.0180 ;$ Fig. 1$)$. In the literature, concentrations above $1 \mu \mathrm{M}$ are described as pharmacological, and physiological concentrations are considered those below $1 \mathrm{nM}$. In general, when used for therapeutic purposes, endogenous substances are administered at concentrations much higher than their physiological secretion, allowing their clinical use $(32,33)$.

Immunocytochemistry. Immunocytochemistry followed by quantification of immunostaining by optical densitometry was used to detect VEGF and HIF-1 $\alpha$ protein expression. The results were obtained in $\mathrm{AU}$ and demonstrated the value of the $\mathrm{MOD} \pm$ standard error.

The HepG2 cells demonstrated an increase in immunostaining of HIF-1 $\alpha$ in cells with induced hypoxia, when compared with the control group $(\mathrm{P}<0.001)$. In cells with induced hypoxia treated with melatonin and cells treated only with melatonin, there was a decrease in immunostaining of HIF-1 $\alpha$ when compared with the control group $(\mathrm{P}<0.001)$ and group with induced hypoxia alone ( $\mathrm{P}<0.001$; Fig. 2A-E).

For VEGF, there was a statistically significant increase in immunostaining in the group with induced hypoxia when compared with the control group $(\mathrm{P}=0.0014)$. As observed for HIF-1 $\alpha$ expression, there was a statistically significant reduction in the immunostaining of VEGF in cells with induced 

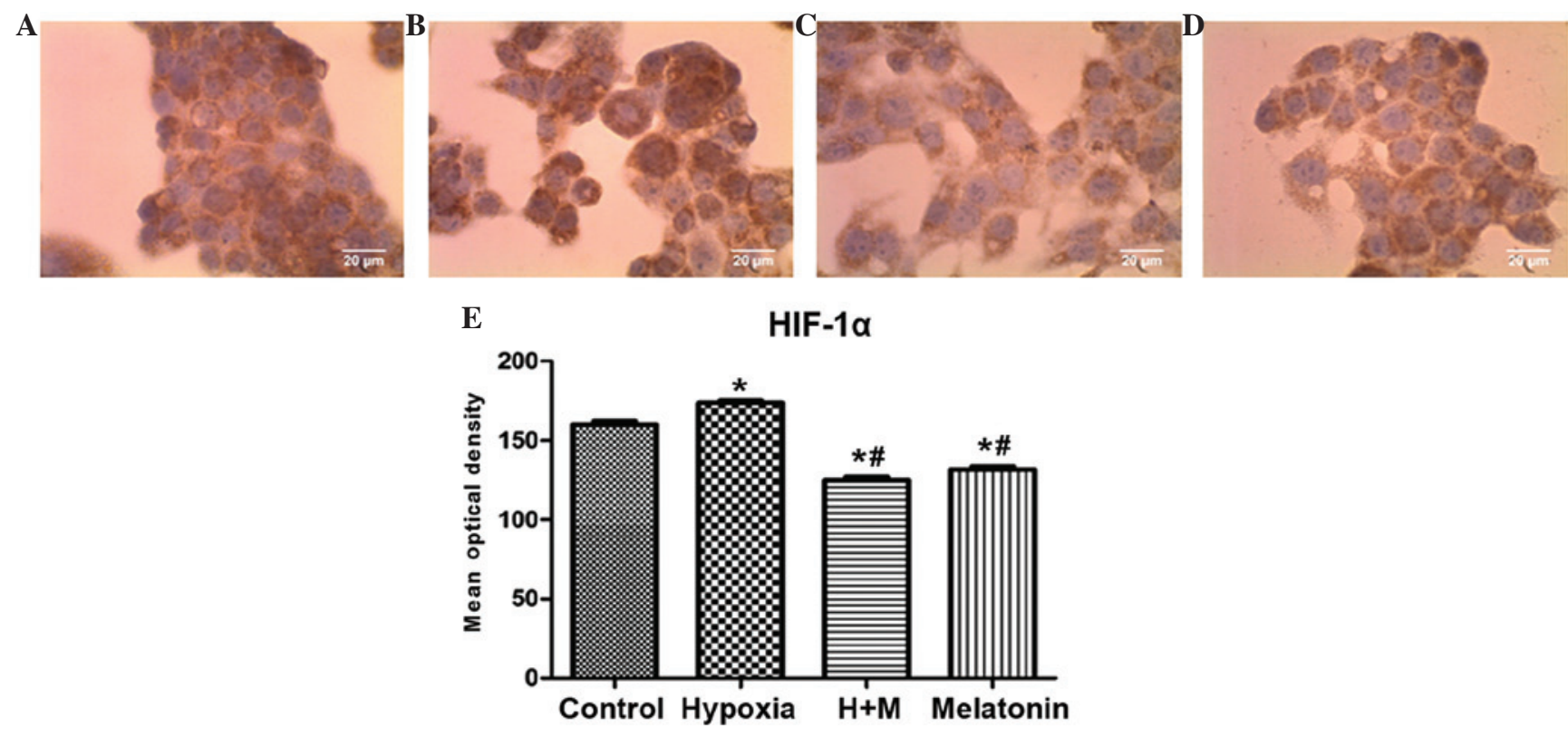

Figure 2. Immunocytochemistry of the protein HIF-1 $\alpha$, showing HepG2 cells (magnification, $\mathrm{x} 40$ ) following $24 \mathrm{~h}$ of treatment with $\mathrm{CoCl}_{2}(100 \mu \mathrm{M})$ for induction of hypoxia and/or melatonin (1 mM). (A) Untreated cells (control group). (B) Cells with induced hypoxia. (C) Cells with induced hypoxia treated with melatonin. (D) Cells treated with melatonin alone. (E) Statistical analysis of protein expression of HIF-1 $\alpha$ in the experimental groups. Data are presented as the mean optical density \pm standard error, and are shown in arbitrary units. " $\mathrm{P}<0.05$ compared with the control group. ${ }^{~} \mathrm{P}<0.05$ compared with cells treated with $\mathrm{CoCl}_{2}$ alone. $\mathrm{H}+\mathrm{M}$, hypoxia and melatonin, $\mathrm{M}$, melatonin; $\mathrm{HIF}-1 \alpha$, hypoxia-inducible factor $1 \alpha$.
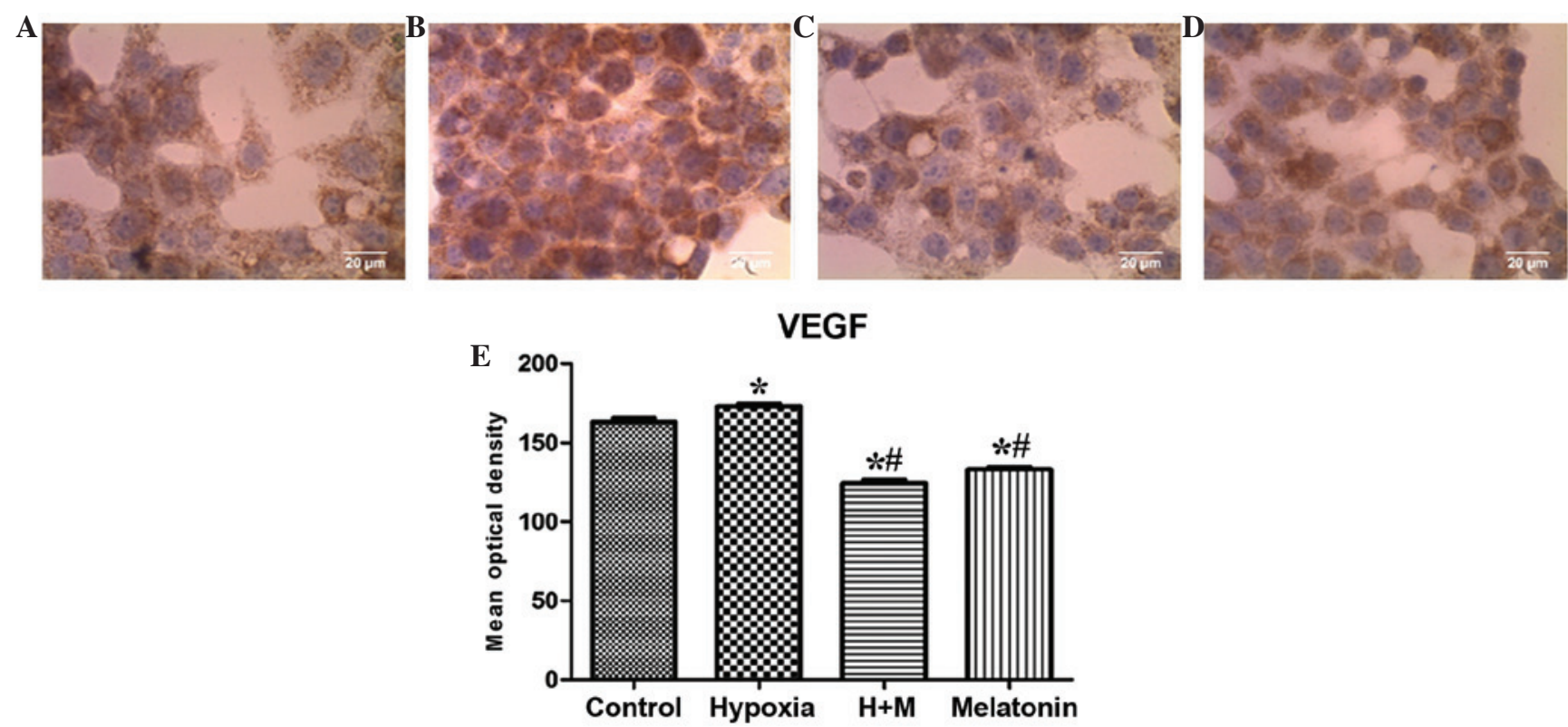

Figure 3. Immunocytochemistry of the protein VEGF, showing HepG2 cells (magnification, $\mathrm{x} 40$ ) following $24 \mathrm{~h}$ of treatment with $\mathrm{CoCl}_{2}(100 \mu \mathrm{M})$ for induction of hypoxia and/or melatonin $(1 \mathrm{mM})$. (A) Untreated cells (control group). (B) Cells with induced hypoxia. (C) Cells with induced hypoxia treated with melatonin. (D) Cells treated with melatonin alone. (E) Statistical analysis of protein expression of VEGF in the experimental groups. Data are presented as the mean optical density \pm standard error, and are shown in arbitrary units. ${ }^{*} \mathrm{P}<0.05$ compared with the control group. ${ }^{*} \mathrm{P}<0.05$ compared with cells treated with $\mathrm{CoCl}_{2}$ alone. $\mathrm{H}+\mathrm{M}$, hypoxia and melatonin; $\mathrm{M}$, melatonin; VEGF, vascular endothelial growth factor.

hypoxia treated with melatonin and in the cells treated only with melatonin when compared with the control group $(\mathrm{P}<0.001)$ and group with induced hypoxia alone $(\mathrm{P}<0.001$; Fig. 3A-E).

Migration and invasion assay. A Transwell chamber assay was performed to investigate the invasion ability of HepG2 cells treated with $1 \mathrm{mM}$ melatonin for $48 \mathrm{~h}$. Treatment was able to reduce the migration and invasion capability of HepG2 cells by $59.5 \%$ when compared with the positive control $(\mathrm{P}=0.0496$; Fig. 4A-B).

\section{Discussion}

The main aim of the present study was to evaluate the effects of melatonin treatment on the expression of proteins associated 

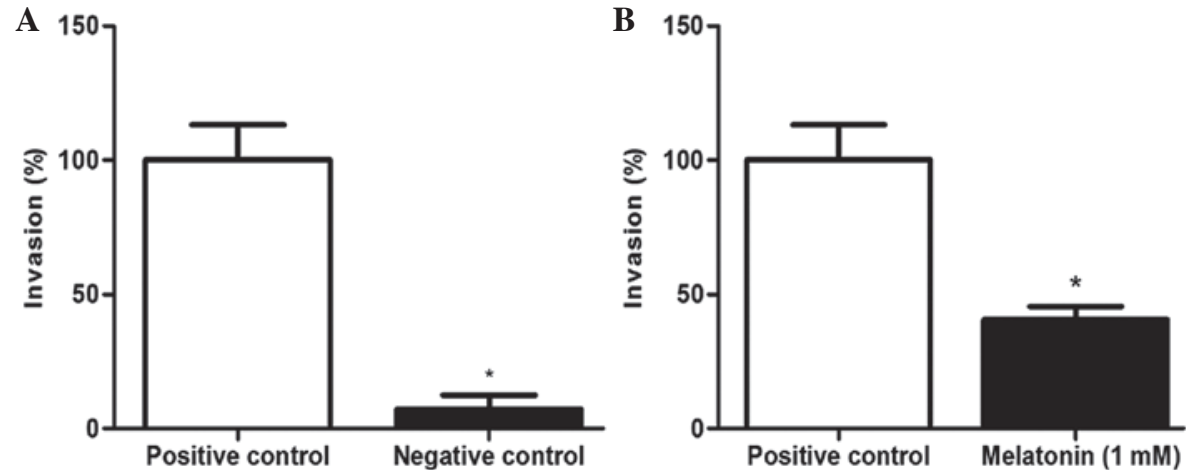

Figure 4. Migration and invasion rate of the HepG2 cell line following $48 \mathrm{~h}$ of treatment with $1 \mathrm{mM}$ melatonin. (A) Comparison between positive and negative control. (B) Comparison between the control with $10 \%$ fetal bovine serum without treatment and cells treated with $1 \mathrm{mM}$ melatonin. Data are presented as the mean \pm standard deviation. ${ }^{*} \mathrm{P}<0.05$.

with angiogenesis and on the invasion ability in hepatocellular carcinoma cells, as these two processes are associated with disease progression and patient prognosis.

In the present study, melatonin decreased viability in the HepG2 cell line. The inhibition of cell proliferation following treatment with melatonin has additionally been observed in other studies, using hepatocarcinoma (34), breast cancer (35) and gastric adenocarcinoma (36) cells. However, the exact mechanism via which melatonin inhibits cell growth in in vitro and in vivo models remains to be fully elucidated, although a number of mechanisms have been proposed. These include induction of apoptosis, changes in the lipid metabolism and an increase in the activity of natural killer cells, as well as stimulation of production of cytokines, including interleukin (IL)-2, IL-6, IL-12 and interferon (37).

Previous studies have additionally demonstrated the antiangiogenic action of melatonin, through decreasing the expression of HIF-1 $\alpha$ in colon (13) and liver cancer cells (24), and glioblastoma (22), as well as decreasing the expression of VEGF in breast (23), pancreatic (5) and liver cancer cells (24).

The results of the present study demonstrate that melatonin treatment in conditions of normoxia and hypoxia inhibited the expression of proangiogenic proteins HIF-1 $\alpha$ and VEGF when compared with the control group and with the group with induced hypoxia alone. Carbajo-Pescador et al (24) and Park et al (13) observed similar results in hepatocellular carcinoma and colon cancer, respectively.

According to Park et al (13), the effects of melatonin treatment on the expression of HIF-1 $\alpha$ and VEGF are primarily observed in hypoxic conditions. This is potentially due to the fact that cell normoxia leads to ubiquitination of HIF-1 $\alpha$ and subsequent proteasomal degradation (30). Nevertheless, under hypoxic conditions, HIF-1 $\alpha$ is stabilized and is able to translocate to the nucleus and induce the expression of multiple genes, including VEGF (30). In addition, although VEGF expression may be directed by growth factors and ILs, it appears that hypoxia, and consequently the expression of HIF-1 $\alpha$, are the principal regulators of VEGF production (38).

However, the present study additionally observed decreased expression of VEGF and HIF-1 $\alpha$ protein in cells treated with melatonin under normoxic conditions when compared with the control. In the work of Carbajo-Pescador et al (24) the expression of VEGF was decreased in normoxic HepG2 cells treated with melatonin compared with the control. However, the expression of HIF-1 $\alpha$ increased in cells treated with melatonin in normoxic conditions (24).

According to Dai et al (30) the effects of the pharmacological concentration of melatonin on VEGF and HIF- $1 \alpha$ expression in normoxic conditions is unclear, which indicates that the regulatory mechanisms of HIF-1 $\alpha$ and VEGF in the absence or presence of $\mathrm{CoCl}_{2}$ are different, and additional transcription factors may be involved.

The decrease in the expression of HIF-1 $\alpha$ and VEGF proteins in HepG2 cells following melatonin treatment in the present study is of particular interest as increased expression of HIF-1 $\alpha$ (39) and VEGF $(7,39)$ correlates with unfavorable prognostic features, including large tumor size and reduced survival in patients with hepatocellular carcinoma.

The regulation of cell invasion is crucial for maintaining cellular homeostasis, and the loss of this regulation is a basic characteristic of cancer cells. The ability of tumor cells to migrate is an important prerequisite for tumor dissemination and metastasis $(15,39)$. A number of studies have additionally indicated that melatonin may have antimetastatic properties and may be able to reduce migration and invasiveness in certain types of cancer, including glioblastoma $(22,25)$, lung (26) and breast cancer cells (27-29). According to Ortíz-López et al (28) melatonin inhibits the migration process and cell invasion in breast cancer cells via the rho-associated-1 protein, by modulating the dynamic cytoskeleton. In addition, Mao et al (29) reported that melatonin exerts an inhibitory effect on breast cancer cell invasion via downregulation of the p38 signaling pathway, and inhibition of matrix metalloproteinase (MMP)-2 and MMP-9 expression and activity.

The results of the present study indicate that treatment with $1 \mathrm{mM}$ melatonin may prevent invasiveness in HepG2 cells and this may be associated with the antimetastatic properties of melatonin. However, the mechanism by which melatonin inhibits the invasiveness of HepG2 cells must be further investigated, as few studies have been performed. According to Ordoñez et al (40) melatonin reduces the invasiveness of the HepG2 hepatocarcinoma cell line in vitro by a molecular mechanism that involves increased expression of TIMP metallopeptidase inhibitor 1 (TIMP-1) and decreased expression and activity of MMP-9, via inhibition of nuclear factor $\kappa-B$. Additionally, in a study performed by Mishra et al (41), it was 
observed that melatonin treatment exerted a hepatoprotective role by downregulation of MMP-9 and upregulation of tissue inhibitor of TIMP-1 expression in liver tissue.

In conclusion, the present study demonstrates that treatment with the pharmacological concentration of melatonin is capable of inhibiting the expression of proangiogenic proteins HIF- $1 \alpha$ and VEGF and invasiveness in vitro in HepG2 cells. In vivo studies are required to support the potential application of melatonin in the treatment of liver cancer.

\section{Acknowledgements}

The present study was made possible by financial support received from FAPESP (Fundação de Amparo à Pesquisa do Estado de São Paulo; grant no., 2013/06421-8), FAMERP (Faculdade de Medicina de São José do Rio Preto; grant no., F-001-004099/2013) and FAPERP (Fundação de Apoio à Pesquisa e Extensão de São José do Rio Preto; grant no., 074/2014).

\section{References}

1. Jemal A, Center MM, DeSantis C and Ward EM: Global patterns of cancer incidence and mortality rates and trends. Cancer Epidemiol Biomarkers Prev 19: 1893-1907, 2010.

2. Yuan GJ, Li QW, Shun SL, Wang WM, Jiang S and Xu XM: Hyperthermia inhibits hypoxia-induced epithelial-mesenchymal transition in HepG2 hepatocellular carcinoma cells. World J Gastroenterol 18: 4781-4786, 2012.

3. Sun XT, Yuan XW, Zhu HT, Deng ZM, Yu DC, Zhou X and Ding YT: Endothelial precursor cells promote angiogenesis in hepatocellular carcinoma. World J Gastroenterol 18: 4925-4933, 2012.

4. Karamysheva AF: Mechanisms of angiogenesis. Biochemistry (Mosc) 73: 751-762, 2008.

5. Lv D, Cui PL, Yao SW, Xu YQ and Yang ZX: Melatonin inhibits the expression of vascular endothelial growth factor in pancreatic cancer cells. Chin J Cancer Res 24: 310-316, 2012.

6. Poon RT, Ng IO, Lau C, Zhu LX, Yu WC, Lo CM, Fan ST and Wong J: Serum vascular endothelial growth factor predicts venous invasion inhepatocellular carcinoma: A prospective study. Ann Surg 233: 227-235, 2001

7. Schoenleber SJ, Kurtz DM, Talwalkar JA, Roberts LR and Gores GJ: Prognostic role of vascular endothelial growth factor in hepatocellular carcinoma: Systematic review and meta-analysis. Br J Cancer 100: 1385-1392, 2009.

8. Kallergi G, Markomanolaki H, Giannoukaraki V, Papadaki MA, Strati A, Lianidou ES, Georgoulias V, Mavroudis D and Agelaki S: Hypoxia-inducible factor-1alpha and vascular endothelial growth factor expression in circulating tumor cells of breast cancer patients. Breast Cancer Res 11: R84, 2009.

9. Flamant L, Notte A, Ninane N, Raes M and Michiels C: Anti-apoptotic role of HIF-1 and AP-1 in paclitaxel exposed breast cancer cells under hypoxia. Mol Cancer 9: 191, 2010.

10. Dales JP, Beaufils N, Silvy M, Picard C, Pauly V, Pradel V, Formisano-Tréziny C, Bonnier P, Giusiano S, Charpin $\mathrm{C}$ and Gabert J: Hypoxia inducible factor 1alpha gene (HIF-1alpha) splice variants: Potential prognostic biomarkers in breast cancer. BMC Med 8: 44, 2010.

11. Greenberg $S$ and Rugo HS: Triple-negative breast cancer: Role of antiangiogenic agents. Cancer J 16: 33-38, 2010.

12. Vordermark D, Kaffer A, Riedl S, Katzer A and Flentje M: Characterization of carbonic anhydrase IX (CA IX) as an endogenous marker of chronic hypoxia in live human tumor cells. Int J Radiat Oncol Biol Phys 61: 1197-1207, 2005.

13. Park SY, Jang WJ, Yi EY, Jang JY, Jung Y, Jeong JW and Kim YJ: Melatonin suppresses tumor angiogenesis by inhibiting HIF-1alpha stabilization under hypoxia. J Pineal Res 48: 178-184, 2010.

14. Shen B, Chu Es, Zhao G, Man K, Wu CW, Cheng JT, Li G, Nie Y, Lo CM, Teoh N, et al: PPARgamma inhibits hepatocellular carcinoma metastasis in vitro and in mice. Br J Cancer 106: 1486-1494, 2012.
15. Shirouzu Y, Ryschich E, Salnikova O, Kerkadze V, Schmidt J and Engelmann G: Rapamycin inhibits proliferation and migration of hepatoma cells in vitro. J Surg Res 159: 705-713, 2010.

16. Aravalli RN, Cressman EN and Steer CJ: Cellular and molecular mechanisms of hepatocellular carcinoma: An update. Arch Toxicol 87: 227-247, 2013.

17. Katyal S, Oliver JH 3rd, Peterson MS, Ferris JV, Carr BS and Baron RL: Extrahepatic metastasis of hepatocellular carcinoma. Radiology 216: 698-703, 2000.

18. Luchetti F, Canonico B, Betti M, Arcangeletti M, Pilolli F, Piroddi M, Canesi L, Papa S and Galli F: Melatonin signaling and cell protection function. FASEB J 24: 3603-3624, 2010.

19. Cutando A, López-Valverde A, Arias-Santiago S, De Vicente J and De Diego RG: Role of melatonin in cancer treatment. Anticancer Res 32: 2747-2753, 2012.

20. Di Bella G, Mascia F, Gualano L and Di Bella L: Melatonin anticancer effects: Review. Int J Mol Sci 24: 2410-2430, 2013.

21. Park JW, Hwang MS, Suh SI and Baek WK: Melatonin down-regulates HIF-1 alpha expression through inhibition of protein translation in prostate cancer cells. J Pineal Res 46: 415-421, 2009.

22. Zhang Y, Liu Q, Wang F, Ling EA, Liu S, Wang L, Yang Y, Yao L, Chen X, Wang F, et al: Melatonin antagonizes hypoxia-mediated glioblastoma cell migration and invasion via inhibition of HIF-1 $\alpha$. J Pineal Res 55: 121-130, 2013.

23. Alvarez-García V, González A, Alonso-González C, Martínez-Campa C and Cos S: Regulation of vascular endothelial growth factor by melatonin in human breast cancer cells. J Pineal Res 54: 373-380, 2013.

24. Carbajo-Pescador S, Ordoñez R, Benet M, Jover R, García-Palomo A, Mauriz JL and González-Gallego J: Inhibition of VEGF expression through blockade of Hifla and STAT3 signalling mediates the anti-angiogenic effect of melatonin in HepG2 liver cancer cells. Br J Cancer 109: 83-91, 2013.

25. Wang J, Hao H, Yao L, Zhang X, Zhao S, Ling EA, Hao A and Li G: Melatonin suppresses migration and invasion via inhibition of oxidative stress pathway in glioma cells. J Pineal Res 53: 180-187, 2012.

26. Zhou Q, Gui S, Zhou Q and Wang Y: Melatonin inhibits the migration of human lung adenocarcinoma A549 cell lines involving JNK/MAPK pathway. PLoS One 9: e101132, 2014.

27. Cos S, Fernández R, Güézmes A and Sánchez-Barceló EJ: Influence of melatonin on invasive and metastatic properties of MCF-7 human breast cancer cells. Cancer Res 58: 4383-4390, 1998.

28. Ortíz-López L, Morales-Mulia S, Ramírez-Rodríguez G and Benítez-King G: ROCK-1 regulated cytoskeletal dynamics participate in the inhibitory effect of melatonin on cancer cell migration. J Pineal Res 46: 15-21, 2009.

29. Mao L, Yuan L, Slakey LM, Jones FE, Burow ME and Hill SM: Inhibition of breast cancer cell invasion by melatonin is mediated through regulation of the p38 mitogen-activated protein kinase signaling pathway. Breast Cancer Res 12: R107, 2010.

30. Dai M, Cui P, Yu M, Han J, Li H and Xiu R: Melatonin modulates the expression of VEGF and HIF-1 alpha induced by $\mathrm{CoCl} 2$ in cultured cancer cells. J Pineal Res 44: 121-126, 2008.

31. Gonçalves Ndo N, Rodrigues RV, Jardim-Perassi BV, Moschetta MG, Lopes JR, Colombo J and Zuccari DA: Molecular markers of angiogenesis and metastasis in lines of oral carcinoma after treatment with melatonin. Anticancer Agents Med Chem 14: 1302-1311, 2014.

32. Yerneni LK and Jayaraman S. Pharmacological action of high doses of melatonin on B16 murine melanoma cells depends on cell number at time of exposure. Melanoma Res 13: 113-117, 2003.

33. Juszczak M, Roszczyk M, Kowalczyk E and Stempniak B: The influence of melatonin receptors antagonists, luzindole and 4-phenyl-2-propionamidotetralin (4-P-PDOT), on melatonin-dependent vasopressin and adrenocorticotropic hormone (ACTH) release from the rat hypothalamo-hypophysial system. In vitro and in vivo studies. J Physiol Pharmacol 65: 777-784, 2014.

34. Fan LL, Sun GP, Wei W, Wang ZG, Ge L, Fu WZ and Wang H: Melatonin and doxorubicin synergistically induce cell apoptosis in human hepatoma cell lines. World J Gastroenterol 16: 1473-1481, 2010. 
35. Margheri M, Pacini N, Tani A, Nosi D, Squecco R, Dama A, Masala E, Francini F, Zecchi-Orlandini S and Formigli L: Combined effects of melatonin and all-trans retinoic acid and somatostatin on breast cancer cell proliferation and death: Molecular basis for the anticancer effect of these molecules. Eur J Pharmacol 681: 34-43, 2012.

36. Zhang S, Qi Y, Zhang H, He W, Zhou Q, Gui S and Wang Y: Melatonin inhibits cell growth and migration, but promotes apoptosis in gastric cancer cell line. Biotech Histochem 88 281-289, 2013.

37. Sainz RM, Mayo JC, Rodriguez C, Tan DX, Lopez-Burillo S and Reiter RJ: Melatonin and cell death: Differential actions on apoptosis in normal and cancer cells. Cell Mol Life Sci 60: 1407-1426, 2003

38. Vaupel P: The role of hypoxia-induced factors in tumor progression. Oncologist 9 (Suppl 5): 10-17, 2004.
39. Xiang ZL, Zeng ZC, Fan J, Tang ZY, Zeng HY and Gao DM: Gene expression profiling of fixed tissues identified hypoxia-inducible factor-1 $\alpha$, VEGF, and matrix metalloproteinase-2 as biomarkers of lymph node metastasis in hepatocellular carcinoma. Clin Cancer Res 17: 5463-5472, 2011.

40. Ordoñez R, Carbajo-Pescador S, Prieto-Dominguez N, García-Palomo A, González-Gallego J and Mauriz JL: Inhibition of matrix metalloproteinase-9 and nuclear factor kappa B contribute to melatonin prevention of motility and invasiveness in HepG2 liver cancer cells. J Pineal Res 56: 20-30, 2014.

41. Mishra A, Paul S and Swarnakar S: Downregulation of matrix metalloproteinase- 9 by melatonin during prevention of alcohol-induced liver injury in mice. Biochimie 93: 854-866, 2011. 